\title{
Robert Steel Morton 1917-2002
}

W ith the death of Robbie Morton on 4 May 2002, 2 months before his 85th birthday, we have lost one of the major influences that helped to shape venereology as a discipline during the post-war period who was instrumental in attracting many doctors into the specialty. Although small in physical stature, he had immense drive and a dynamic personality allied to great communication skills that endeared him to his colleagues and students.

Robbie was born on 5 July 1917 and brought up in Glasgow, where he attended Hutcheson's Grammar School for Boys. He qualified from medical school in Glasgow in 1939. With call up to the services inevitable at the time of his qualification, he decided that 6 months in general practice would be more relevant than a house appointment. $\mathrm{He}$ spent the next 6 years in the Royal Army Medical Corps. Most of his time was spent in the surgical division with special responsibilities for blood transfusion and resuscitation, but he also spent 6 months each in venereology and infectious diseases. He spent over 3 years serving in the Middle East and was awarded the MBE for distinguished service in Greece and Crete in 1942 at the age of 24. Subsequently, he was attached to a district hospital in South Wales, before the Normandy invasion, where he met his future wife, Peggy. They worked together in Europe and married in 1945. Their marriage and family life was the rock upon which all of his later success was based.

After leaving the services, Robbie returned to Glasgow for a refresher course as a supernumerary medical registrar, and decided upon a career in venereology. He trained in Newcastle upon Tyne, then one of the largest and most progressive provincial units in the post-war years. Basil Schofield was a contemporary. He was appointed to his first consultant post in Stockport and Manchester in 1951 where he spent the next 9 years, during which time he obtained his MRCP from the Edinburgh College in 1953, subsequently being elected to the fellowship in 1962. In his early consultant days, he practised comprehensive sexual health medicine, which in addition to management of sexually transmitted infection also included contraception, subfertility, and marriage guidance. He also had weekly sessions within the serology laboratory

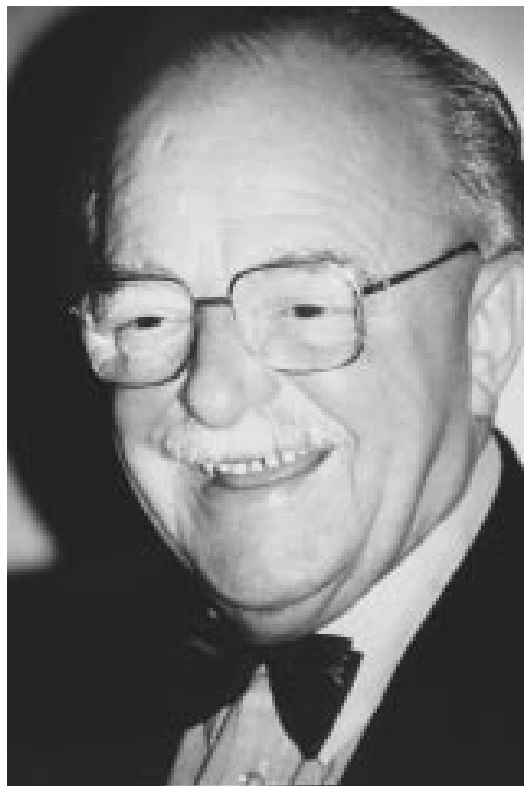

memorable one liners that made learning easy. He recognised the advent of the sexual revolution, when sex changed from "a procreational to a recreational activity", and the liberating effect upon women of effective contraception. While he recognised the association of STIs with other health consequences of socioeconomic deprivation, he also contrasted gonorrhoea as a disease more prevalent during times of relative prosperity with syphilis, which often re-emerged in times of hardship and recession. He also strongly advocated the development of an adolescent health specialty to better meet the complex needs of young people.

During the late 1960s, 10 or more students would be present in the consulting room with him, all sitting on a bench, and one would be selected to accompany him to examine the patient behind a screen after the history had been taken. Ironically, the Royal Infirmary Roundhouse, where this took place, has now been preserved as a listed building, whereas most of the remaining hospital, including Robbie's new clinic, has been demolished and replaced by a supermarket. The respect and affection in which his students held him was shown by the many 10 and 20 year reunions that he attended as guest speaker. He also inspired many Sheffield graduates to consider venereology as a challenging and respectable career choice.

Unlike in many other towns and cities, relationships with gynaecologists were very amicable, and venereology became taught and examined as an integral part of the obstetrics and gynaecology student attachment. He also played a large part in encouraging doctors who had received their general professional training in O\&G to train in venereology. He was especially proud to have trained 17 consultants before his retirement from the NHS in 1977. For many he continued to be a mentor throughout his life. He also encouraged many women to join the specialty, in an era when the discipline consisted almost exclusively of male consultants. He successfully fought against discrimination at all levels, although in his latter years he found it increasingly difficult to deal with what he experienced as the worst kind-that of ageism.

Robbie was a staunch supporter of his junior doctors. He was ahead of his time in insisting that all new doctors have an induction period of several weeks while they sat in on his clinics and teaching cal characters who was caring of his specialty and his patients. He also had many 
sessions before they were allowed to see patients independently. He taught all how to write and generously shared his ideas and work. All staff were required to produce at least one publication every year, and he would ensure this by co-authoring papers with those whose inspiration or application was lacking.

His contributions were not limited to south Yorkshire. Robbie served as member of the MSSVD Council continuously for 20 years from 1958, was ideally suited (as a canny Scot) to look after its finances as treasurer from 1960-7, and was elected as the society president during 1967-8. He was elected as an honorary fellow in 1982 and continued to be a regular attendee of society meetings and a challenging, sometimes confrontational, questioner of our guest speakers until just before his death. He was invited to deliver the ninth Harrison Lecture at the 75th anniversary spring meeting held in Oxford in 1997. He was also a member of the BMA Venereologists Committee for 16 years, the chair of the SAC in genitourinary medicine for the Joint Committee on Higher Medical Training, and the external examiner for the Liverpool Diploma in Venereology.

He was also active on a global basis. Between 1969 and 1977, he undertook a series of short term consultancies for the World Health Organization in Singapore, Bangladesh, New Zealand, Somalia, and Jamaica. Following his retirement from the NHS in 1977, he spent a year as visiting venereologist in Western Australia and then a further year as visiting scientist at the Center for Disease Control and Prevention in Atlanta where he was chiefly concerned with education and training. Subsequently, he spent further time in Washington DC, Jamaica, South Africa, and South East Asia. He continued to perform regular consultant locums for the district general hospitals in North Trent until 1993.

His local research contribution was recognised by the University of Sheffield in 1982, when he was awarded an honorary MD, and in the same year he was also awarded the Sutherland Trust Scholarship, which enabled him to undertake a 4 week lecture tour in New Zealand, and honorary memberships of both the Swedish Society of Dermatovenereology and Singapore Society of Dermatology. He was also invited to give the Osler Lecture at the Society of Apothecaries, where he was thrilled to have been placed first in the Diploma of the History of Medicine examination in 1984, and was the first McEligott lecturer at St Mary's Hospital in 1985.

Throughout his career, Robbie was a prolific writer. In addition to publishing numerous scientific papers and serving on the editorial board of the journal for many years, he also produced a number of publications for the general public. Penguin books first published his paperback entitled The Venereal Diseases in 1966 and this was also translated into French, German, Spanish, and Portuguese. In 1968, he produced for the BMA VD and Diseases Transmitted Sexually, which ran to five editions and numerous reprints. He produced a monograph "Gonorrhoea" in 1977, and wrote many reports and publications for the World Health Organization, where he was held in such high esteem that he had been invited to submit an application for the post of chief of VD and treponematoses in 1971.
After his retirement, Robbie was able to give more time to his passion for medical history and produced many memorable articles. He developed an avid interest in the pathogenesis and natural history of genital chlamydial infections. Altogether, after his retirement, Robbie had no less than 55 peer reviewed publications in the scientific literature. He also had non-medical publications in the field of antiques. MSSVD only recently was able to obtain his extensive collection of rare historical manuscripts, which is now housed in the Royal Society of Medicine library.

Although Robbie had a cardiac pacemaker fitted some 20 years ago, he had remained in robust health up until the sudden onset of his final illness, a massive cerebral haemorrhage. Although he could just about have coped with the physical restrictions that a dense hemiplegia had imposed, he would have found it almost unbearable to be unable to communicate because of the associated aphasia. Although he did regain consciousness for a time, he gradually deteriorated over the following weeks and died peacefully, surrounded by his wife and family.

Sadly, he will no longer be there in person either at our postgraduate meetings in Sheffield or at our society meetings in London and will be greatly missed. However, the society has his book collection, and his spirit, values, and tradition will live on in Sheffield and beyond.

He leaves a wife, Peggy, two sons, Jock and Angus, five grandchildren, and four great grandchildren.

George Kinghorn 